\title{
THE FATE OF ECTOMYCORRHIZAL FUNGI ASSOCIATED WITH PINUS RADIATA SEEDLINGS IN THE NURSERY
}

\author{
K. WALBERT ${ }^{1}$, T.D. RAMSFIELD ${ }^{1}$, M.A. DICK ${ }^{1}$, E.E. JONES ${ }^{2}$ \\ and H.J. RIDGWAY ${ }^{2}$ \\ ${ }^{1}$ Scion, Forest Biosecurity and Protection, Private Bag 3020, Rotorua, \\ New Zealand \\ ${ }^{2}$ Bio-Protection and Ecology Division, Lincoln University, Lincoln, \\ New Zealand
}

Corresponding author: Katrin.Walbert@scionresearch.com

\begin{abstract}
Ectomycorrhizal (ECM) fungi dramatically enhance the growth of the plantation species Pinus radiata and facilitate the establishment of nursery seedlings following outplanting. This study investigated ECM species colonising P. radiata seedlings in the nursery and their fate in the first year of outplanting. Naturally occurring ECM communities of $P$. radiata seedlings in the Te Ngae Nursery, Rotorua, were investigated and these seedlings were assessed following outplanting in Kaingaroa Forest. Observations of the ECM communities were made eight times during the first year of the seedlings being in the plantation forest. In addition, the ECM communities of 1,2 and 8 year old $P$. radiata plantation stands were also analysed. It was found that nursery ECM survived the first year of outplanting. The first non-nursery ECM, Pezizales sp., occurred 6 months after outplanting at Kaingaroa, but these were in minor abundance. Rhizopogon rubescens was the most persistent and dominant nursery ECM species. Overall, nursery ECM survived for 2 years following outplanting but were completely replaced by 7 years.
\end{abstract}

\section{NEW HOST ASSOCIATION FOR SIREX NOCTILIO AND AMYLOSTEREUM AREOLATUM ON CEDRUS ATLANTICA}

\author{
G.M. BURNIP ${ }^{1}$, I.C. HARVEY ${ }^{2}$, D. VOICE ${ }^{1}$ and M. BRAITHWAITE ${ }^{1}$ \\ ${ }^{1}$ Ministry of Agriculture and Forestry, PO Box 24, Lincoln, New Zealand \\ ${ }^{2}$ PLANTwise Services Limited, PO Box 181, Lincoln, New Zealand \\ Corresponding author: graham.burnip@maf.govt.nz
}

Wood boring larvae, considered to be Sirex wood wasp, were found together with its symbiot, the pathogenic Amylostereum fungi, associated with ca 20 dead and dying cedar trees at a Christchurch golf club. MAF Biosecurity New Zealand was contacted because it was thought that the Sirex was possibly a species not present in New Zealand, such as Sirex juvencus or Urocerus gigas (both high impact forest pests), since the single Sirex species present here (Sirex noctilio) had not previously been recorded attacking Cedrus $\mathrm{sp}$. (cedar) in New Zealand or elsewhere. Furthermore, if the Sirex was a recent incursion of a new to New Zealand species, the Amylostereum fungi might also have been an exotic species. Further examinations revealed a single adult Sirex (live, pre-emergence) within a larval tunnel. This allowed definitive morphological identification as Sirex noctilio, the species already present in New Zealand. Molecular diagnostics (direct sequencing) determined the fungi to be Amylostereum areolatum; the Amylostereum fungi commonly found in association with Sirex noctilio in New Zealand Pinus spp. Investigations suggest tree stress (probably non-target herbicide impacts) resulted in the cedar becoming susceptible to Sirex noctilio attack. This represents a new record of association between Sirex noctilio and Amylostereum areolatum on Cedrus atlantica host. 